\title{
Effects of Dietary Crude Protein on Protein and Fat Deposition in Milk-Fed Veal Calves
}

\author{
E. Labussiere, ${ }^{\star} \dagger \neq$ S. Dubois, ${ }^{\star} \dagger$ J. van Milgen, ${ }^{\star} \dagger$ G. Bertrand, $\neq$ and J. Noblet ${ }^{\star} \dagger^{1}$ \\ *Institut National de la Recherche Agronomique, UMR1079 SENAH, F-35000 Rennes, France \\ †Agrocampus Ouest, UMR1079 SENAH, F-35000 Rennes, France \\ łlnstitut de l'Elevage, Monvoisin, BP 85225, F-35652 Le Rheu Cedex, France
}

\section{ABSTRACT}

Research on veal calf production has focused on maximizing lean tissue growth. Nevertheless, limited attention has been paid to the evolution of digestive and metabolic utilization of $\mathrm{N}$ and energy as calves get older, whereas age at slaughter increases. The objective of this study was to determine the effects of 4 concentrations of dietary crude protein $(\mathrm{CP})$ content on protein and fat deposition and energy utilization in milk-fed calves at 3 stages of fattening using the balance technique combined with heat production measurements in a respiration chamber. At each stage, 16 Prim'Holstein male calves (mean body weight at each stage: 72,136 , and $212 \mathrm{~kg}$ ) received 4 isocaloric diets with $\mathrm{CP}$ contents of $76,88,100$, and $112 \%$ of a reference $\mathrm{CP}$ content fixed at $20 \%$ during the first stage and $19 \%$ during the 2 later stages. After $2 \mathrm{wk}$ of adaptation to their respective diets and housing conditions, the calves were placed for $1 \mathrm{wk}$ in an open-circuit respiration chamber for $\mathrm{N}$ and energy balance measurements (first $6 \mathrm{~d}$ ) and measurement of the fasting heat production (last day). Measurements for a stage were performed over 2 periods of 4 successive weeks. There was no effect of dietary CP on digestibility during the 2 later stages, but the lowprotein diet resulted in lower digestibility coefficients for dry matter, organic matter, gross energy, CP, and crude fat during the first stage. Endogenous fecal $\mathrm{N}$ was estimated as $2.5 \mathrm{~g} / \mathrm{kg}$ of dry matter intake irrespective of stage, and metabolic urinary $\mathrm{N}$ was estimated at 0.07 $\mathrm{g} / \mathrm{kg}$ of body weight ${ }^{0.85}$ per day. Maximum $\mathrm{N}$ retention was $32.8,40.5$, and $44.0 \mathrm{~g} / \mathrm{d}$ at stages 1,2 , and 3 , respectively. The effect of protein intake on protein deposition was dependent on age of the calves, because the marginal efficiency of digestible protein utilization decreased from 64 to $18 \%$ as animals got older. Fat deposition decreased with increasing dietary $\mathrm{CP}$ content irrespective of stage. Total energy retention was not modified by dietary CP content. The composition

Received March 25, 2008.

Accepted August 4, 2008.

${ }^{1}$ Corresponding author: jean.noblet@rennes.inra.fr of body weight gain was affected differently for each stage, because the protein content of body weight gain increased with increasing dietary $\mathrm{CP}$ content during the first stage, whereas it remained constant during the other 2 stages. Fat and energy content in body weight gain decreased with increasing dietary $\mathrm{CP}$ irrespective of stage. These results provide a basis for estimating protein requirement of veal calves according to a factorial approach.

Key words: veal calf, protein intake, protein and fat retention, heat production

\section{INTRODUCTION}

Research on veal calf production has focused on maximizing lean tissue growth. Due to the increasing cost of milk derivatives used in milk replacers, more attention has to be devoted to maximizing the efficiency of nutrient utilization, in particular proteins, to produce lean tissue. Furthermore, optimizing dietary CP concentrations contribute to decreasing excess $\mathrm{N}$ excretion. Recent studies on protein requirements of veal calves have mainly focused on young animals (Blome et al., 2003; Bartlett et al., 2006). When older animals were used, growth performance was measured over longer periods of time with little focus on the evolution of digestive and metabolic utilization of nutrients and energy (Gerrits et al., 1996). Moreover, genotypes of calves have progressively changed in Europe (predominance of Prim'Holstein), and BW and age at slaughter have increased.

The changing context and the relative lack of recent data justify a reevaluation of the protein requirements of veal calves. The objective of this study was to quantify the effect of dietary $\mathrm{CP}$ concentration on $\mathrm{N}$ and energy utilization for protein and lipid deposition and on heat production (HP) in veal calves over the whole rearing period ( $25 \mathrm{wk})$.

\section{MATERIALS AND METHODS}

The present experiment complied with French ethic laws and was conducted under the direction of J. No- 
blet (authorization number 04739) and G. Bertrand (authorization number 07558).

\section{Experimental Design}

This experiment was designed to determine the effect of 4 concentrations of dietary protein on protein and lipid deposition and on HP in veal calves during 3 stages: stage 1 (from 5 to $8 \mathrm{wk}$ in rearing), stage 2 (from 13 to $16 \mathrm{wk}$ ), and stage 3 (from 21 to $24 \mathrm{wk}$ ), that is, a 4 -wk delay between successive stages. Week 1 corresponds to the first week after purchasing and arrival at the facilities at 7 to $15 \mathrm{~d}$ of actual age. The measurements were conducted on 4 calves per protein concentration at each stage and consisted of a $6-\mathrm{d} \mathrm{N}$ and energy balance followed by a fasting day for estimating the fasting HP (FHP). Because only 2 large respiration chambers were available, 2 balances could be performed weekly. Two successive batches of calves were used, and measurements were alternated between batches; calves of the second batch were purchased 4 wk after the first batch. The average age for balance measurements was equivalent for the 4 dietary treatments and 2 batches.

\section{Experimental Diets}

Four grower diets differing in their CP contents were used during stage 1 , and 4 finisher diets differing in their $\mathrm{CP}$ contents were used during stages 2 and 3 . Diets were formulated to include skim milk powder, $50 \%$ fat-enriched skim milk powder (fat constituted $80 \%$ tallow and $20 \%$ coconut oil), and lactose (Table 1). The $\mathrm{CP}$ concentrations were considered relative to a reference CP concentration, which was $20 \%$ for grower diets and 19\% for finisher diets. For each type of diet, the $4 \mathrm{CP}$ concentrations contained $76,88,100$, and $112 \%$ of the reference concentration of $\mathrm{CP}$ and were referred to as G76, G88, G100, and G112 for the grower diets and F76, F88, F100, and F112 for the finisher diets. Differences in CP concentrations were achieved by substituting skim milk powder for the $50 \%$-fat enriched skim milk powder plus lactose so that $\mathrm{CP}$ replaced a mixture of lactose and fat at the same gross energy concentration. Titanium dioxide was included in the finisher diets as an indigestible marker to correct for possible incomplete feces collection. Because feces were collected without losses, marker data were not further used in the calculations. Diets were supplemented with L-lysine, DL-methionine, L-threonine, and L-tryptophan to achieve an ideal AA profile as proposed by Labussière et al. (2007).

Liquid milk was reconstituted just before distribution by dissolving the diets in hot water at a concentration increasing from 130 to $175 \mathrm{~g}$ of $\mathrm{DM} / \mathrm{kg}$ of reconstituted milk as the calf got older. This milk was offered at a temperature ranging from 45 to $50^{\circ} \mathrm{C}$ in 2 equal meals at 0845 and $1800 \mathrm{~h}$. Quantities of DM offered daily and calf BW during measurements are given in Table 2. During the fasting day, calves only received a morning meal with diets they had received during the previous $6 \mathrm{~d}$ and were fasted thereafter. To limit disturbance in performance due to the insufficient protein supply, calves were offered the reference diet (G100 or F100) when they were not in the adaptation or measurement period.

\section{Animals, Housing, and Management}

Two batches of 14 male Prim'Holstein calves were used in this experiment. Measurements were conducted on 8 calves per batch and per stage. Three calves of each batch were assigned to a CP concentration allowing 2 supplementary calves per batch. These calves could be used to replace others of the same batch in case of problems. Each week, 2 calves receiving 2 different $\mathrm{CP}$ concentrations were moved from the pen to cages with a wood-slatted floor at the experimental station of the Institut de l'Elevage (Le Rheu, France). After 1 wk, calves were transferred to the Institut National de la Recherche Agronomique (INRA) facilities (SaintGilles, France; $10 \mathrm{~km}$ distance from Le Rheu) for further adaptation and measurements. Upon arrival, they were housed for a 1-wk adaptation period using the same metabolism cages. The cages were placed in the same room but separated by a curtain to avoid visual contacts between the 2 animals. Calves were bucket-fed automatically without human intervention just before distribution. The automated feeding procedure consisted of distributing the reconstituted milk through the bottom of the bucket. This milk was previously stored and constantly stirred in a plastic can. After $10 \mathrm{~min}$, refusals were pumped out through the bottom of the bucket and $1 \mathrm{~L}$ of hot water (at approximately $60^{\circ} \mathrm{C}$ ) was poured in the bucket and pumped to the plastic can to rinse the system. Refusals and rinse water were collected together and stored. Two days before entrance in the respiration chamber, a harness with plastic bag was attached to the calves to allow total collection of feces.

During the measurement week, the calf in its metabolism cage was placed in a $12-\mathrm{m}^{3}$ open-circuit respiration chamber (Vermorel et al., 1973). The cage was mounted on force sensors, which produced an electrical signal indicative for the physical activity of the calf. The position of the animal (standing or lying) was evaluated using an infrared beam placed across the cage at the bottom of the hip. The temperature and relative humidity in the chamber were maintained constant at 
Table 1. Composition of milk replacers

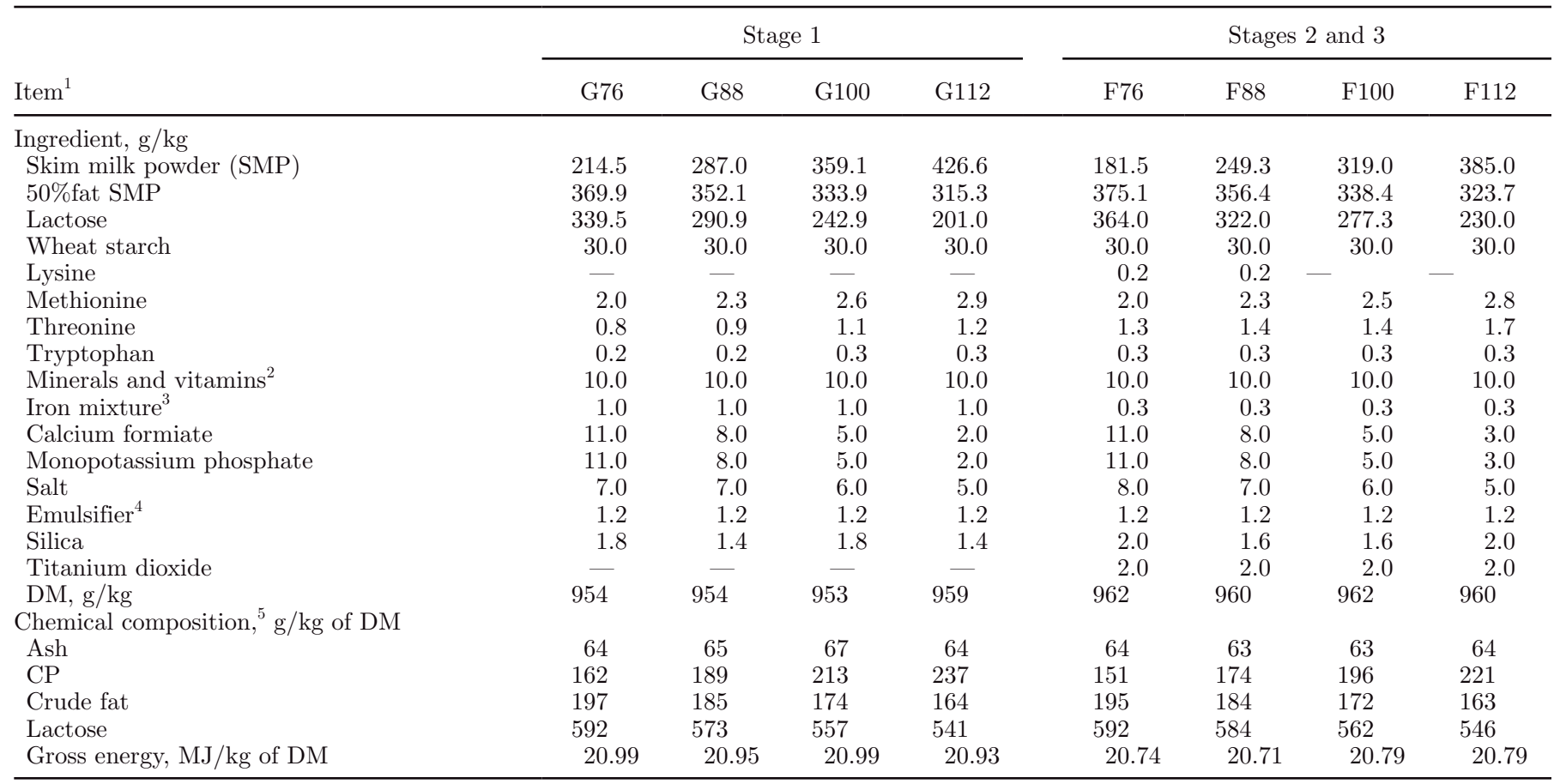

${ }^{1}$ The CP content of diets G76 to G112 and F76 to F112 was determined as 76 to $112 \%$ of a reference CP content of 200 and $190 \mathrm{~g} / \mathrm{kg}$ for grower and finisher diets, respectively.

${ }^{2}$ The minerals and vitamins mixture provided (per gram of mixture): magnesium, $45 \mathrm{mg}$; retinol, 2,000 IU; cholecalciferol, $400 \mathrm{IU}$; $\alpha$ tocopherol, $8 \mathrm{mg}$; ascorbic acid, $15 \mathrm{mg}$; thiamin, $1 \mathrm{mg}$; riboflavin, $1 \mathrm{mg}$; pyridoxin, $0.8 \mathrm{mg}$; cyanocobalamin, $0.008 \mathrm{mg}$; niacin, $4 \mathrm{mg}$; pantothenic acid, $2 \mathrm{mg}$; menadione, $0.25 \mathrm{mg}$; biotin, $0.01 \mathrm{mg}$; folic acid, $0.15 \mathrm{mg}$; choline, $50 \mathrm{mg}$; betaine, $20 \mathrm{mg}$; iron, $1 \mathrm{mg}$; copper, $1 \mathrm{mg}$; zinc, $4 \mathrm{mg}$; manganese, $5 \mathrm{mg}$; cobalt, $0.04 \mathrm{mg}$; iodine, $0.045 \mathrm{mg}$; selenium, $0.02 \mathrm{mg}$, Lactalis Industrie, Bourgbarré, France.

${ }^{3}$ The iron mixture provided (per gram of mixture): thiamin, $4 \mathrm{mg}$; cyanocobalamin, $0.08 \mathrm{mg}$; folic acid, $1 \mathrm{mg}$; iron, $18.5 \mathrm{mg}$; copper, $4.8 \mathrm{mg}$; cobalt, $0.5 \mathrm{mg}$, Lactalis Industrie.

${ }^{4}$ The emulsifying agent contained soy fatty acids, polyethylene glycol, glycerol (60\%), and silica (40\%), Cognis, Düsseldorf, Germany.

${ }^{5}$ As measured.

$18^{\circ} \mathrm{C}$ and $70 \%$, respectively. A 12 -h lighting time span (from 0730 to $1930 \mathrm{~h}$ ) was used. The 2 separate respiration chambers were equipped with microphones and speakers so that calves could hear each other. Calves were offered the reconstituted milk as in the adaptation week.

\section{Measurements}

Calves were weighed upon arrival at the INRA facilities and at entrance in the respiration chamber before the morning meal. During the first stage of measurements, all calves were weighed on the morning before and after the fasting day. This procedure required the complete opening of the respiration chamber and may also cause stress to the animal. Because of this, this procedure was partly abandoned for the 2 later stages in which calves of the first batch were still weighed before and after fasting, whereas calves of the second batch were only weighed after the fasting day: BW of these calves on the morning before fasting was estimated using a linear relationship between $\mathrm{BW}$ prior

Table 2. Age (week of fattening), milk replacer offered, and mean BW of veal calves during balance measurements

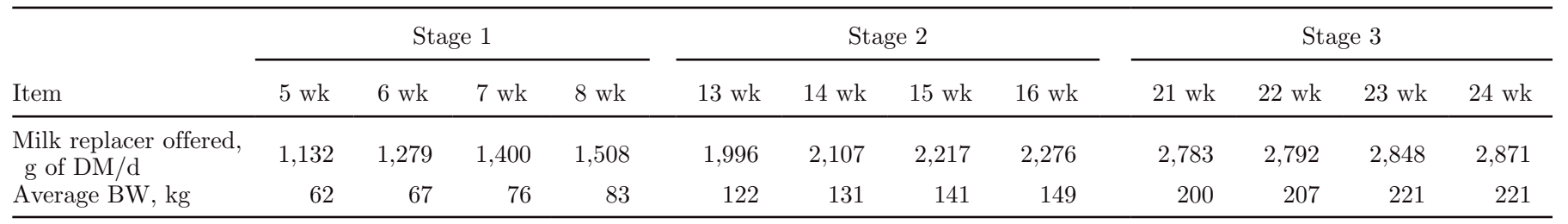


and after fasting obtained from the calves of the first batch $\left(\mathrm{BW}_{\text {prior fasting }}=0.43+1.01 \times \mathrm{BW}_{\text {after fasting }}, \mathrm{R}^{2}\right.$ $=0.99)$.

The quantity of milk offered to each calf when housed at the INRA facilities was weighed, and milk replacer was sampled over the balance period. Samples were pooled by diet and stage. Diluted refusals were weighed for each calf after each meal, and a 20-mL sample was frozen. Feces were collected and weighed daily, stored at $-20^{\circ} \mathrm{C}$, and pooled per calf over the 6 - $\mathrm{d}$ period. Urine was collected in buckets containing 120 $\mathrm{mL}$ (stage 1) or $240 \mathrm{~mL}$ (stages 2 and 3) of $\mathrm{H}_{2} \mathrm{SO}_{4}(1.8$ $\mathrm{mol} / \mathrm{L}$ ) to prevent volatilization of $\mathrm{NH}_{3}$ and weighed daily. An aliquot was taken and pooled per calf over the 6 - $\mathrm{d}$ balance period and stored at $+4^{\circ} \mathrm{C}$ awaiting further analysis.

Gas concentrations $\left(\mathrm{CO}_{2}, \mathrm{O}_{2}\right.$, and $\left.\mathrm{CH}_{4}\right)$ of outgoing air and ventilation rate were recorded continuously according to methods described by van Milgen et al. (1997). The $\mathrm{O}_{2}$ concentration was measured with a paramagnetic differential analyzer (Oxymat 6, Siemens AG, Munich, Germany), whereas the $\mathrm{CO}_{2}$ concentration was measured with an infrared analyzer (Ultramat 6, Siemens AG, or Unor 600, Maihak AG, Hamburg, Germany). A single $\mathrm{CH}_{4}$ analyzer (Unor $6 \mathrm{~N}$, Maihak AG) was available for the 2 respiration chambers, and $\mathrm{CH}_{4}$ concentration was measured during the first $3 \mathrm{~d}$ for one respiration chamber and during the following 3 $\mathrm{d}$ for the other one. Gas extraction rate was measured with a mass gas meter (Teledyne Brown Engineering, Hampton, VA). Gas concentrations, the signals of the force sensors, the weight of the distribution recipient, gas flow rate, temperature, and relative humidity in the respiration chamber were measured 60 times per second, averaged over 10-s intervals, and recorded for further calculations. Ammonia losses in the air recovered in condensed water and outgoing air were collected according to methods described by Noblet et al. (1987).

\section{Chemical Analyses}

Samples of feed (1 per diet) were analyzed for DM, ash, N, ether extract, lactose, and gross energy contents according to standard methods (AOAC, 1990); N content was also analyzed on feed samples taken weekly, and CP content was calculated assuming a converting factor equivalent to 6.38. Samples of diluted refusals were analyzed for DM, and its DM composition was supposed to be identical to the feed offered. Fecal samples were similarly analyzed for DM, ash, ether extract, $\mathrm{N}$, and gross energy content. Samples of urine were analyzed for $\mathrm{N}$ content on fresh material. Gross energy content in the urine was obtained after freeze-drying approximately $30 \mathrm{~mL}$ in polyethylene bags. The $\mathrm{NH}_{3}$ content of condensed water and extracting air was determined on fresh material using an enzymatic method (Enzytec fluid, Scil Diagnostics GmbH, Martinsried, Germany).

\section{Calculations}

Mean growth rate of the calf for the overall adaptation and balance period (12 d) was calculated using estimated BW on the morning after the arrival at the INRA facilities and the BW on the morning of the fasting day. The former was obtained by applying an adjustment function to the BW measured at the arrival at the facilities (calves arrived in the middle of the day). The adjustment function $\left(0.24+0.98 \times \mathrm{BW}_{\text {at arrival }} ; \mathrm{R}^{2}\right.$ $=0.99$ ) was determined from data obtained from another trial in which calves were actually weighed twice (at arrival and at the next day before feeding). Growth rate was also calculated for the balance period only (i.e., during the presence in the respiration chamber and while fed). Assuming a constant growth rate, this latter value was used to estimate each morning BW over the balance measurement period.

The DMI and apparent digestibility coefficients of $\mathrm{DM}, \mathrm{OM}, \mathrm{N}$, gross energy, and ether extract were calculated according to standard procedures. Nitrogen retention $(\mathbf{R N})$ of each calf was calculated as the difference between ingested $\mathrm{N}$ and $\mathrm{N}$ losses in feces, urine, condensed water, and $\mathrm{NH}_{3}-\mathrm{N}$ in extracted air (called evaporated). Digestible energy (DE) intake was calculated as the difference between gross energy intake and energy excreted in the feces, whereas ME intake was calculated as the difference between DE and energy losses in the urine. Methane production was negligible and therefore not included in calculations. Total HP was calculated from $\mathrm{O}_{2}$ consumption and $\mathrm{CO}_{2}$ production according to the formula of Brouwer (1965). The first day in respiration chamber was considered as an adaptation day, and all calculations were carried out for the 5 subsequent days. Energy retention was calculated as the difference between daily ME intake and average HP. Assuming an energy content of the protein gain of $23.6 \mathrm{~kJ} / \mathrm{g}$ (van den Borne et al., 2006b), energy retained as protein was calculated from the $\mathrm{N}$ balance (energy retained as protein $=\mathrm{RN} \times 6.25 \times 23.6)$, and energy retained as fat was calculated as the difference between total energy retained and energy retained as protein. Fat deposition was calculated assuming an energy content of $39.7 \mathrm{~kJ} / \mathrm{g}$. The protein and lipid concentrations of the BW gain were calculated by relating deposition to mean growth rate over the 12 consecutive days of adaptation and measurements.

Simultaneous measurements of $\mathrm{O}_{2}$ and $\mathrm{CO}_{2}$ concentrations in the respiration chamber, signals of force 
sensors, feed intake (time of distribution and ingested quantity), and physical characteristics of gas exchanges in the chamber were used to calculate the components of HP according to the modeling approach of van Milgen et al. (1997). In brief, the variations in $\mathrm{O}_{2}$ and $\mathrm{CO}_{2}$ concentrations in the respiration chamber were related to events occurring in the chamber and resulting in gas exchanges due to feed intake and physical activity in addition to the gas exchanges corresponding to basal metabolic rate. The HP due to physical activity, feed intake (short-term effect of feeding), and resting metabolism were calculated from the respective volumes of $\mathrm{O}_{2}$ consumption and $\mathrm{CO}_{2}$ production using the formula of Brouwer (1965) excluding urinary N losses. During the fasting day, the $\mathrm{O}_{2}$ consumption and $\mathrm{CO}_{2}$ production during the last $12 \mathrm{~h}$ were used to estimate the FHP using the method described by van Milgen et al. (1997), corresponding to the asymptotic value of metabolic rate at zero activity. The difference between HP due to resting metabolism and FHP was assumed to correspond to a long-term effect of feeding and, combined with the short-term effect of feeding, allows calculating the total thermic effect of feeding. Results about FHP and HP due to physical activity have been combined with data of another trial and published by Labussière et al. (2008); they will not be considered in detail here. All energy measurements are expressed relative to $\mathrm{BW}^{0.85}$ per day (Labussière et al., 2008).

\section{Statistical Analysis}

Data were analyzed separately for stage 1 but together for stages 2 and 3, according to the type of diets (grower or finisher) the calves received. Data for stage 1 were analyzed including the effects of diet and week of measurement, and those for stages 2 and 3 were analyzed including the effects of diet, stage, week of measurements (within stage), and interaction between diet and stage. The PROC GLM of SAS (2004) was used according to the following models:

$$
\begin{gathered}
\mathrm{Y}=\mu+\mathrm{D}+\mathrm{W}+\varepsilon \text { for stage } 1, \\
\mathrm{Y}=\mu+\mathrm{D}+\mathrm{S}+\mathrm{W}(\mathrm{S})+\mathrm{D} \times \mathrm{S}+\varepsilon \text { for stages } 2 \text { and } 3
\end{gathered}
$$

where $\mathrm{Y}=$ the dependent variable; $\mu=$ the intercept; $\mathrm{D}=$ the effect of diet; $\mathrm{W}=$ the effect of week of measurements within a stage; $\mathrm{S}=$ the effect of stage of fattening (only for stages 2 and 3 ); and $\varepsilon=$ an error term. Equality of LSM was tested according to a Student test.

Endogenous $\mathrm{N}$ losses were considered to be proportional to DM intake (Davis and Drackley, 1998; NRC,
2001) and estimated from the relationship between digestible $\mathrm{N}(\mathbf{D N})$ and $\mathrm{N}$ intake, expressed per kilogram of DMI. The effects of stage of fattening on both the intercept and the slope were tested. The maintenance $\mathrm{N}$ requirement (recovered as metabolic urinary $\mathrm{N}$ ) was estimated from the relationship between $\mathrm{RN}$ and DN for the calves $(\mathrm{n}=11$ for stages 1 and 2 and $\mathrm{n}=4$ for stage 3) receiving quantities of $\mathrm{DN}$ below the requirement for maximal growth according to NRC (2001). Because metabolic urinary $\mathrm{N}$ was assumed to depend on metabolic body size, DN and RN were expressed per kilogram of $\mathrm{BW}^{0.85}$ (Labussière et al., 2008). The effect of stage of fattening was not considered due to the decreasing number of values as stage increased. Nitrogen balances were also pooled across stages, and a linear relationship between $\mathrm{RN}$ and $\mathrm{DN}$ was used in the following model:

$$
\mathrm{RN}=\mathrm{S} \times \mathrm{DN}+\mathrm{S}+\varepsilon,
$$

where $S=$ the effect of stage and $\varepsilon=$ an error term. Equality of parameters across stages was tested using PROC GLM of SAS (2004).

\section{RESULTS}

Composition of the diets is given in Table 1, and characteristics were as anticipated. There were no major difficulties during the balance measurements. Four calves had some feed refusals or difficulties of adaptation during the adaptation week at INRA; they were replaced by other calves that received the same dietary treatment.

\section{Growing Stage}

The results given in Table 3 indicate that mean BW, DMI, and BW gain over the growing period were not affected by dietary $\mathrm{CP}$ concentration and averaged 71.9 $\mathrm{kg}, 1,300 \mathrm{~g}$ of $\mathrm{DM} / \mathrm{d}$, and $0.98 \mathrm{~kg} / \mathrm{d}$, respectively. Both BW and DMI increased with time. Apparent fecal digestibility coefficients for DM, OM, gross energy, CP, and crude fat were lower $(P<0.05)$ for diet G76 than for diet G100. Consequently, the DE content of diet G76 was lower than the other grower diets $(P=0.03)$. The metabolizability of DE was not affected by CP concentration and averaged $97.1 \%$, but it decreased from 97.4 (average value for wk 5 to 7 of fattening) to $96.4 \%$ during wk 8 of fattening $(P=0.04)$. Consequently, the ME content of diet G76 was the lowest $(P=0.01)$.

According to the experimental strategy, $\mathrm{N}$ intake increased with dietary CP content from 32.4 to 48.8 $\mathrm{g} / \mathrm{d}$ (Table 4). Daily fecal N excretion was not affected 
Table 3. Effect of dietary CP concentration on performance and apparent fecal digestibility during stage 1 in veal calves $(\mathrm{n}=16)$

\begin{tabular}{|c|c|c|c|c|c|c|c|}
\hline Item & \multicolumn{4}{|c|}{ Diet $^{1}$} & SEM & \multicolumn{2}{|c|}{$P$-value } \\
\hline $\mathrm{BW}, \mathrm{kg}$ & 69.6 & 71.2 & 72.7 & 74.2 & 2.2 & 0.20 & $<0.01$ \\
\hline BW gain, ${ }^{2} \mathrm{~kg} / \mathrm{d}$ & 0.90 & 0.97 & 0.95 & 1.09 & 0.03 & 0.20 & 0.54 \\
\hline \multicolumn{8}{|c|}{ Digestibility coefficients, $\%$} \\
\hline DM & $94.9^{\mathrm{b}}$ & $96.1^{\mathrm{ab}}$ & $97.2^{\mathrm{a}}$ & $95.7^{\mathrm{b}}$ & 0.3 & 0.02 & 0.92 \\
\hline Crude fat & $92.8^{\mathrm{b}}$ & $94.3^{\mathrm{ab}}$ & $96.1^{\mathrm{a}}$ & $95.8^{\mathrm{a}}$ & 0.5 & 0.04 & 0.46 \\
\hline ME:DE, \% & 96.7 & 97.4 & 96.9 & 97.6 & 0.2 & 0.13 & 0.04 \\
\hline \multicolumn{8}{|c|}{ Energy values, $\mathrm{MJ} / \mathrm{kg}$ of $\mathrm{DM}$} \\
\hline $\mathrm{DE}$ & $19.67^{\mathrm{b}}$ & $20.05^{\mathrm{a}}$ & $20.26^{\mathrm{a}}$ & $20.03^{\mathrm{a}}$ & 0.07 & 0.03 & 0.75 \\
\hline $\mathrm{ME}$ & $19.02^{\mathrm{b}}$ & $19.53^{\mathrm{a}}$ & $19.64^{\mathrm{a}}$ & $19.55^{\mathrm{a}}$ & 0.08 & 0.01 & 0.51 \\
\hline
\end{tabular}

${ }^{a, b}$ Least squares means within a row with different superscripts differ $(P<0.05)$.

${ }^{1}$ Crude protein concentrations in diets: G76 $=162 \mathrm{~g} / \mathrm{kg}$ of DM; G88 = $189 \mathrm{~g} / \mathrm{kg}$ of DM; G100 = $213 \mathrm{~g} / \mathrm{kg}$ of DM; G112 = $237 \mathrm{~g} / \mathrm{kg}$ of DM.

${ }^{2}$ Body weight gain calculated over the combined adaptation and balance periods.

by $\mathrm{CP}$ concentration or week of measurement and averaged $2.9 \mathrm{~g} / \mathrm{d}$. Urinary $\mathrm{N}$ excretion increased from 6.7 to $12.4 \mathrm{~g} / \mathrm{d}$ as dietary $\mathrm{CP}$ content increased $(P<0.01)$. Urinary N also increased with age from 7.8 to $11.9 \mathrm{~g} / \mathrm{d}$ $(P<0.01)$. The quantities of $\mathrm{N}$ recovered in the air extracted from the respiration chamber and in the condensed water were constant and negligible $(0.1 \mathrm{~g} / \mathrm{d})$. Nitrogen retained in the body increased from 22.3 to $32.8 \mathrm{~g} / \mathrm{d}$ with $\mathrm{CP}$ concentration in the $\operatorname{diet}(P<0.01)$. Expressed as a percentage of DN, RN was not affected by $\mathrm{CP}$ concentration and averaged $74.5 \%$.

As indicated in Table 5, daily ME intake and HP $\left(\mathrm{kJ} / \mathrm{kg}\right.$ of $\mathrm{BW}^{0.85}$ per day) were not affected by $\mathrm{CP}$ concentration and tended to increase with time $(P=0.08$ and $P=0.06$, respectively). Components of HP were neither affected by concentration of $\mathrm{CP}$ nor by week of measurement. Retained energy was not significantly affected by dietary CP concentration, but energy retained as protein increased from 89 to $125 \mathrm{~kJ} / \mathrm{kg}$ of $\mathrm{BW}^{0.85}$ per day $(P<0.01)$, whereas energy retained as lipid was decreased from 157 to $102 \mathrm{~kJ} / \mathrm{kg}$ of $\mathrm{BW}^{0.85}$ per day $(P<0.01)$ when $\mathrm{CP}$ concentration was increased from the lowest to the highest concentration. The respiratory quotient was not affected by $\mathrm{CP}$ concentration, although the value for diet G76 was numerically greater (0.96 vs. $0.94 ; P=0.18$ ).

Protein deposition increased from 139 to $205 \mathrm{~g} / \mathrm{d}$ (Table 5, $P<0.01$ ), whereas lipid deposition decreased from 146 to $99 \mathrm{~g} / \mathrm{d}(P<0.01)$ with increasing $\mathrm{CP}$ concentration in the diet. Consequently, the protein content of BW gain increased from 154 to $187 \mathrm{~g} / \mathrm{kg}$ $(P=0.01)$, whereas the lipid content decreased from 163 to $90 \mathrm{~g} / \mathrm{kg}(P<0.01)$. The energy content of gain tended to decrease as dietary $\mathrm{CP}$ content increased $(P$ $=0.08)$. Protein and fat deposition increased from 149 to $197 \mathrm{~g} / \mathrm{d}(P<0.01)$ and from 107 to $137 \mathrm{~g} / \mathrm{d}(P=$ $0.04)$, respectively, between wk 5 and 8 .

\section{Finishing Stages}

During stages 2 and 3, mean BW of the calves during measurement periods was not affected by diets (Table

Table 4. Effect of dietary $\mathrm{CP}$ on $\mathrm{N}$ utilization during stage 1 in veal calves $(\mathrm{n}=16)$

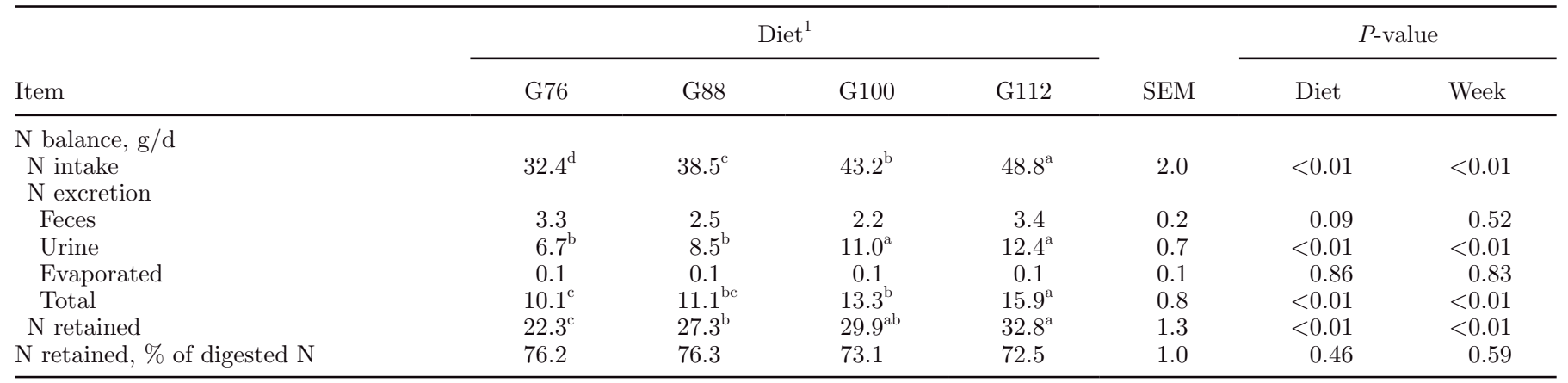

${ }^{\mathrm{a}-\mathrm{d}}$ Least squares means within a row with different superscripts differ $(P<0.05)$.

${ }^{1}$ Crude protein concentrations in diets: G76 $=162 \mathrm{~g} / \mathrm{kg}$ of DM; G88 = $189 \mathrm{~g} / \mathrm{kg}$ of DM; G100 = $213 \mathrm{~g} / \mathrm{kg}$ of DM; G112 = $237 \mathrm{~g} / \mathrm{kg}$ of DM. 
Table 5. Effect of dietary CP on energy balance, respiratory quotient, and nutrient deposition in veal calves during stage $1(\mathrm{n}=16)$

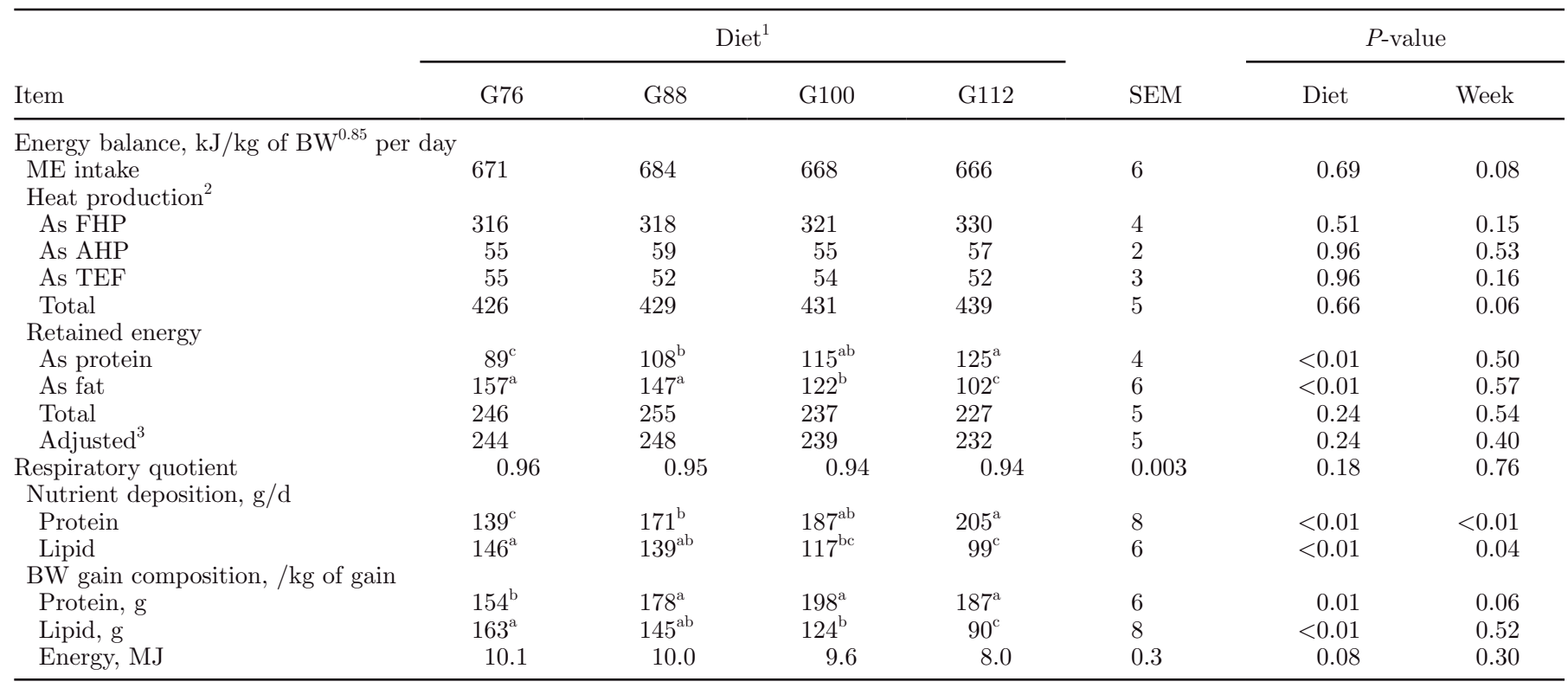

${ }^{\mathrm{a}-\mathrm{c}}$ Least squares means within a row with different superscripts differ $(P<0.05)$.

${ }^{1}$ Crude protein concentrations in diets: G76 = $162 \mathrm{~g} / \mathrm{kg}$ of DM; G88 = $189 \mathrm{~g} / \mathrm{kg}$ of DM; G100 = $213 \mathrm{~g} / \mathrm{kg}$ of DM; G112 = $237 \mathrm{~g} / \mathrm{kg}$ of DM. ${ }^{2} \mathrm{FHP}=$ fasting heat production; AHP $=$ activity heat production; TEF $=$ thermic effect of feeding.

${ }^{3}$ Retained energy was adjusted for the same ME intake and AHP (respectively, 672 and $57 \mathrm{~kJ} / \mathrm{kg}$ of BW ${ }^{0.85}$ per day, i.e., average values for stage $1)$.

6) and averaged 136 and $212 \mathrm{~kg}(P<0.01)$ during stages 2 and 3, respectively. Dietary $\mathrm{CP}$ concentration did not affect DM intake, which increased from 2,106 to $2,757 \mathrm{~g}$ of $\mathrm{DM} / \mathrm{d}$ between stages 2 and 3 . The BW gain increased from 1.17 to $1.45 \mathrm{~kg} / \mathrm{d}$ when dietary $\mathrm{CP}$ content increased during stage 2 , but it remained constant and averaged $1.44 \mathrm{~kg} / \mathrm{d}$ during stage $3(P=$ $0.05)$. There was no effect of stage, diet, or week on the apparent fecal digestibility coefficients of OM and gross energy, which were all greater than $93 \%$. The digestibility of $\mathrm{CP}$ of the finisher diets was numerically lower than during stage 1 but did not differ between diets or stages and averaged $91.3 \%$. The digestibility coefficient of fat was not affected by dietary $\mathrm{CP}$ content $(P=$ 0.07), except that diets F88 and F112 gave extreme results during stage 2 . The metabolizability of DE was lower during stage 3 than during stage $2(P=0.04)$ but did not differ between diets. The DE content of the diet was lower with diet F88 than with diet F112 $(P=$ 0.04). The ME content of the finisher diets was greater in stage 2 than in stage $3(P=0.03)$.

As expected, daily $\mathrm{N}$ intake was affected by stage, diet, and week (Table 7, $P<0.01$ ). Fecal $\mathrm{N}$ excretion was greater during stage 3 than during stage 2 (7.2 vs. $5.0 \mathrm{~g} / \mathrm{d} ; P<0.01$ ), but it did not differ between diets or week of measurement within a stage. Total $\mathrm{N}$ excretion increased during stages 2 and 3 when the $\mathrm{CP}$ concentration in the diet increased $(P<0.01)$. This was mainly due to the increased $\mathrm{N}$ excretion in the urine $(P<0.01)$. Despite significant treatment effects, evaporated $\mathrm{N}$ remained a small fraction of $\mathrm{N}$ excretion in stage 2 and 3. Nitrogen retention was greater during stage 3 than during stage 2 ( 42 vs. $37 \mathrm{~g} / \mathrm{d}$ ), but it only tended to increase with the dietary $\mathrm{CP}$ concentration $(P=0.06)$. When expressed as a percentage of $\mathrm{DN}$, RN decreased from 72.5 with F76 during stage 2 to $49.5 \%$ with diet F112 during stage 3 as CP concentration in the diet increased and as animals got older $(P$ $<0.01)$.

According to the experimental design, ME intake $\left(\mathrm{kJ} / \mathrm{kg}\right.$ of $\mathrm{BW}^{0.85}$ per day) was equivalent for all diets within a stage and was greater during stage 2 than during stage 3 (Table 8,611 vs. $529 \mathrm{~kJ} / \mathrm{kg}$ of $\mathrm{BW}^{0.85}$ per day, $P<0.01)$. The total HP was not affected by dietary $\mathrm{CP}$ concentration but differed between stages with greater values during stage 2 than during stage 3 (400 vs. $363 \mathrm{~kJ} / \mathrm{kg}$ of $\mathrm{BW}^{0.85}$ per day, $P<0.01$ ). This was mainly due to a greater FHP (305 vs. $272 \mathrm{~kJ} / \mathrm{kg}$ of $\mathrm{BW}^{0.85}$ per day, $\left.P<0.01\right)$. Total energy retention was lower during stage 3 than during stage 2 (211 vs. 166 $\mathrm{kJ} / \mathrm{kg}$ of $\mathrm{BW}^{0.85}$ per day, $\left.P<0.01\right)$. Energy retained as protein did not differ between diets but was lower during stage 3 than during stage 2 (65 vs. $84 \mathrm{~kJ} / \mathrm{kg}$ of $\mathrm{BW}^{0.85}$ per day, $\left.P<0.01\right)$. During both stages, energy retained as fat was greater for diet F76 compared with the other diets $(P<0.01)$, and values were greater dur- 
Table 6. Effect of dietary $\mathrm{CP}$ on performance and apparent fecal digestibility during stages 2 and 3 in veal calves $(\mathrm{n}=32)$

\begin{tabular}{|c|c|c|c|c|c|c|c|c|c|c|c|c|c|}
\hline \multirow[b]{2}{*}{ Item } & \multicolumn{4}{|c|}{ Stage 2} & \multicolumn{4}{|c|}{ Stage 3} & \multirow[b]{2}{*}{ SEM } & \multicolumn{4}{|c|}{$P$-value } \\
\hline & $\mathrm{F} 76^{1}$ & $\mathrm{~F} 88^{1}$ & $\mathrm{~F} 100^{1}$ & $\mathrm{~F} 112^{1}$ & F76 & F88 & F100 & F112 & & Stage & Diet & Week & Diet $\times$ stage \\
\hline $\mathrm{BW}, \mathrm{kg}$ & 130.9 & 135.9 & 138.2 & 138.9 & 208.2 & 211.9 & 216.0 & 213.0 & 7.1 & $<0.01$ & 0.19 & $<0.01$ & 0.95 \\
\hline DM intake, $\mathrm{g} / \mathrm{d}$ & 2,113 & 2,101 & 2,128 & 2,081 & 2,795 & 2,781 & 2,751 & 2,702 & 61 & $<0.01$ & 0.31 & $<0.01$ & 0.70 \\
\hline $\mathrm{BW}$ gain, ${ }^{2} \mathrm{~kg} / \mathrm{d}$ & $1.17^{\mathrm{b}}$ & $1.25^{\mathrm{b}}$ & $1.53^{\mathrm{a}}$ & $1.45^{\mathrm{a}}$ & $1.45^{\mathrm{a}}$ & $1.33^{\mathrm{ab}}$ & $1.53^{\mathrm{a}}$ & $1.44^{\mathrm{a}}$ & 0.03 & 0.03 & $<0.01$ & 0.61 & 0.05 \\
\hline \multicolumn{14}{|c|}{ Digestibility coefficients, \% } \\
\hline $\mathrm{DM}$ & 95.0 & 94.3 & 96.0 & 96.3 & 94.5 & 95.0 & 95.0 & 95.5 & 0.2 & 0.30 & 0.06 & 0.70 & 0.33 \\
\hline $\mathrm{OM}$ & 96.0 & 95.3 & 96.8 & 97.3 & 95.6 & 96.0 & 95.3 & 96.5 & 0.2 & 0.27 & 0.22 & 0.93 & 0.37 \\
\hline Gross energy & 94.5 & 93.5 & 95.8 & 96.3 & 94.5 & 95.0 & 93.8 & 95.5 & 0.3 & 0.57 & 0.18 & 0.96 & 0.17 \\
\hline $\mathrm{CP}$ & 91.0 & 89.3 & 92.5 & 93.8 & 90.3 & 91.3 & 90.3 & 92.3 & 0.4 & 0.50 & 0.18 & 0.97 & 0.39 \\
\hline Crude fat & 93.3 & 90.8 & 94.3 & 96.3 & 92.8 & 94.0 & 92.5 & 94.5 & 0.4 & 0.81 & 0.07 & 0.99 & 0.11 \\
\hline ME:DE, \% & 93.8 & 93.5 & 95.0 & 95.5 & 92.5 & 91.8 & 94.0 & 93.0 & 0.4 & 0.04 & 0.25 & 0.34 & 0.89 \\
\hline \multicolumn{14}{|c|}{ Energy values, $\mathrm{MJ} / \mathrm{kg}$ of $\mathrm{DM}$} \\
\hline $\mathrm{DE}$ & $20.00^{\mathrm{a}}$ & $19.50^{\mathrm{ab}}$ & $20.00^{\mathrm{a}}$ & $20.00^{\mathrm{a}}$ & $19.50^{\mathrm{ab}}$ & $19.25^{\mathrm{b}}$ & $19.75^{\mathrm{ab}}$ & $20.00^{\mathrm{a}}$ & 0.08 & 0.10 & 0.04 & 0.80 & 0.69 \\
\hline ME & 18.50 & 18.00 & 19.25 & 19.25 & 18.00 & 18.00 & 18.25 & 18.50 & 0.13 & 0.03 & 0.06 & 0.57 & 0.50 \\
\hline
\end{tabular}

${ }^{\mathrm{a}-\mathrm{c}}$ Least squares means within a row with different superscripts differ $(P<0.05)$.

${ }^{1}$ Crude protein concentrations in diets: F76 $=151 \mathrm{~g} / \mathrm{kg}$ of DM; F88 = $174 \mathrm{~g} / \mathrm{kg}$ of DM; F100 = $196 \mathrm{~g} / \mathrm{kg}$ of DM; F112 = $221 \mathrm{~g} / \mathrm{kg}$ of DM.

${ }^{2}$ Body weight gain calculated over the combined adaptation and balance periods.

Table 7. Effect of dietary $\mathrm{CP}$ on $\mathrm{N}$ utilization during stages 2 and 3 in veal calves $(\mathrm{n}=32)$

\begin{tabular}{|c|c|c|c|c|c|c|c|c|c|c|c|c|c|}
\hline \multirow[b]{2}{*}{ Item } & \multicolumn{4}{|c|}{ Stage 2} & \multicolumn{4}{|c|}{ Stage 3} & \multirow[b]{2}{*}{ SEM } & \multicolumn{4}{|c|}{$P$-value } \\
\hline & $\mathrm{F} 76^{1}$ & $\mathrm{~F} 88^{1}$ & $\mathrm{~F} 100^{1}$ & $\mathrm{~F} 112^{1}$ & F76 & F88 & F100 & F112 & & Stage & Diet & Week & Diet $\times$ stage \\
\hline \multicolumn{14}{|l|}{$\mathrm{N}$ balance, $\mathrm{g} / \mathrm{d}$} \\
\hline $\mathrm{N}$ intake & $49.5^{\mathrm{g}}$ & $56.8^{\mathrm{f}}$ & $65.3^{\mathrm{e}}$ & $71.8^{\mathrm{d}}$ & $66.5^{\mathrm{e}}$ & $76.7^{\mathrm{c}}$ & $85.5^{\mathrm{b}}$ & $93.6^{\mathrm{a}}$ & 2.5 & $<0.01$ & $<0.01$ & $<0.01$ & 0.32 \\
\hline \multicolumn{14}{|l|}{$\mathrm{N}$ excretion } \\
\hline Feces & 4.4 & 6.0 & 4.7 & 4.6 & 6.4 & 6.9 & 8.1 & 7.4 & 0.3 & $<0.01$ & 0.63 & 0.94 & 0.51 \\
\hline Urine & $12.2^{\mathrm{f}}$ & $16.2^{\mathrm{ef}}$ & $20.9^{\mathrm{de}}$ & $26.5^{\mathrm{cd}}$ & $20.1^{\mathrm{e}}$ & $28.1^{\mathrm{bc}}$ & $32.8^{\mathrm{b}}$ & $42.2^{\mathrm{a}}$ & 1.7 & $<0.01$ & $<0.01$ & 0.30 & 0.32 \\
\hline Evaporated & $0.1^{\mathrm{e}}$ & $0.2^{\mathrm{de}}$ & $0.2^{\mathrm{e}}$ & $0.2^{\mathrm{de}}$ & $0.4^{\text {cd }}$ & $0.7^{\mathrm{b}}$ & $0.6^{\mathrm{bc}}$ & $1.0^{\mathrm{a}}$ & 0.1 & $<0.01$ & $<0.01$ & 0.50 & 0.03 \\
\hline Total & $16.7^{\mathrm{f}}$ & $22.4^{\mathrm{e}}$ & $25.8^{\mathrm{de}}$ & $31.3^{\mathrm{cd}}$ & $26.9^{\mathrm{de}}$ & $35.7^{\mathrm{c}}$ & $41.5^{\mathrm{b}}$ & $50.7^{\mathrm{a}}$ & 1.9 & $<0.01$ & $<0.01$ & 0.16 & 0.13 \\
\hline $\mathrm{N}$ retained & 32.8 & 34.4 & 39.5 & 40.5 & 39.6 & 41.0 & 44.0 & 42.9 & 0.9 & $<0.01$ & 0.06 & 0.97 & 0.76 \\
\hline $\mathrm{N}$ retained, $\%$ of digested $\mathrm{N}$ & $72.5^{\mathrm{a}}$ & $67.8^{\mathrm{ab}}$ & $65.3^{\mathrm{abc}}$ & $60.3^{\mathrm{bc}}$ & $66.0^{\mathrm{abc}}$ & $58.8^{\text {bcd }}$ & $57.3^{\text {cd }}$ & $49.5^{\mathrm{d}}$ & 1.5 & $<0.01$ & $<0.01$ & 0.80 & 0.92 \\
\hline
\end{tabular}

${ }^{\mathrm{a}-\mathrm{f}}$ Least squares means within a row with different superscripts differ $(P<0.05)$.

${ }^{1}$ Crude protein concentrations in diets: F76 $=151 \mathrm{~g} / \mathrm{kg}$ of DM; F88 = $174 \mathrm{~g} / \mathrm{kg}$ of DM; F100 = $196 \mathrm{~g} / \mathrm{kg}$ of DM; F112 = $221 \mathrm{~g} / \mathrm{kg}$ of DM. 
ing stage 2 . The respiratory quotient was not affected by stage or diet and averaged 0.93 .

The protein content of BW gain did not vary with diet or stage and averaged $178 \mathrm{~g} / \mathrm{kg}$ (Table 8). The lipid and energy contents of BW gain decreased with increasing $\mathrm{CP}$ content of the diet $(P<0.01)$.

\section{Utilization of $\mathbf{N}$ from Grower and Finisher Diets}

The relationship between daily DN and $\mathrm{N}$ intake (g/ $\mathrm{kg}$ of DM intake per day) is presented in Table 9. There was no effect of stage of fattening on the intercept or slope of the regression. The intercept differed significantly from $0(-2.5 \mathrm{~g} / \mathrm{kg}$ of DM intake, $P<0.01)$, whereas the slope was not different from unity. As explained earlier, the regression between $\mathrm{RN}$ and $\mathrm{DN}(\mathrm{g} /$ $\mathrm{kg}$ of $\mathrm{BW}^{0.85}$ per day) included only the data of calves that received DN amounts lower than their theoretical $\mathrm{N}$ requirements. The intercept of the relation was not different from 0 , whereas the slope was $0.81(P<$ 0.01). Moreover, the $\mathrm{N}$ content of BW gain estimated by regression was $28.3 \mathrm{~g} / \mathrm{kg}$ (i.e., $177 \mathrm{~g}$ of protein $/ \mathrm{kg}, P$ $<0.01$ ) and did not depend on stage of growth.

The linear relationships between $\mathrm{RN}$ and $\mathrm{DN}(\mathrm{g} / \mathrm{d}$ ) are illustrated in Figure 1. The slope of the regression decreased from $0.64(P<0.01)$ at stage 1 to $0.40(P$ $<0.01)$ and $0.18(P=0.02)$ at stages 2 and 3 , respectively. The slopes differed between stages 1 and $2(P=$ $0.04)$ and tended to differ between stages 2 and $3(P$ $=0.10)$.

\section{DISCUSSION}

\section{Digestive Utilization of Diets}

For both grower and finisher diets, the digestibility coefficients for DM and energy were greater than $93 \%$. This is due to the high digestibility of skim milk and is consistent with earlier reports (Roy et al., 1970; Ternouth et al., 1985; Guilloteau et al., 1986). Nevertheless, digestibility coefficients for nutrients of the low-protein diet were always the lowest during stage 1 , which may be due to the greater concentration of carbohydrates, causing digestive disturbances (Lodge and Lister, 1973). In addition, the digestibility of CP is an apparent value, and values are logically lower for the low$\mathrm{CP}$ diets during stage 1 due to a greater proportion of endogenous secretions in excreted $\mathrm{N}$. The daily amount of fecal $\mathrm{N}$ at each stage remained constant for all diets, which means that the true fecal digestibility of dietary CP was $100 \%$ as also estimated in Table 9 (Tolman and Beelen, 1995). Therefore, the $\mathrm{N}$ recovered in feces was only of endogenous origin; the $2.5 \mathrm{~g}$ of endogenous $\mathrm{N} / \mathrm{kg}$ of DMI (Table 9) is slightly greater than values reported before for veal calves $(2.2 \mathrm{~g} / \mathrm{kg}$ of DMI; Davis and Drackley, 1998; $1.9 \mathrm{~g} / \mathrm{kg}$ of DMI; NRC, 2001; 2.0 $\mathrm{g} / \mathrm{kg}$ of DMI; van den Borne et al., 2006b).

\section{Utilization of Digestible Dietary Protein}

Traditionally, part of the urinary $\mathrm{N}$ is considered as a component of the maintenance $\mathrm{N}$ requirements. This latter part was estimated in our experiment as $0.07 \mathrm{~g} /$ $\mathrm{kg}$ of $\mathrm{BW}^{0.85}$ per day, which does not differ from 0 and is in the lower range of the literature values (Labussière et al., 2007). Nevertheless, the range of variation in DN might not have been sufficient to precisely estimate this component, which also appears variable in the literature (0.10 to $0.20 \mathrm{~g} / \mathrm{kg}$ of $\mathrm{BW}^{0.75}$ per day). Additionally, our value was expressed as a function of $\mathrm{BW}^{0.85}$, whereas literature data were expressed as $\mathrm{BW}^{0.75}$. Because of difference in scaling, our estimate (expressed as g/d) remains close to the lower bound of literature data and increases from 2.0 to $7.6 \mathrm{~g} / \mathrm{d}$ when BW increases from 50 to $250 \mathrm{~kg}$, whereas the higher bound of the literature data increases up to $12.6 \mathrm{~g} / \mathrm{d}$ for a $250-\mathrm{kg}$ BW calf.

A decrease in the efficiency of utilization of DN with age or BW has been observed previously (van Weerden, 1972; Labussière et al., 2007). Nevertheless, the maximum values observed in the present study $(76,73$, and $66 \%$ for stages 1,2 , and 3 , respectively) are in the upper range of values reported in the literature, which range from 60 to $70 \%$ for grower calves (Ternouth et al., 1985; Diaz et al., 2001; Blome et al., 2003; Bartlett et al., 2006) to 55 to $60 \%$ for finisher calves (Gerrits et al., 1996; van den Borne et al., 2006b). We used milk proteins supplemented with AA to obtain an optimal AA profile (Labussière et al., 2007). This may have improved the efficiency of protein utilization. Moreover, maximum $\mathrm{N}$ utilization was obtained with the lowest DN intake in agreement with Donnelly and Hutton (1976a). Efficiency values of DN utilization reported in the literature have been usually obtained at greater concentrations of DN (48 to $63 \mathrm{~g} / \mathrm{d}$, Ternouth et al., 1985; 73 to $89 \mathrm{~g} / \mathrm{d}$, Diaz et al., 2001; $80 \mathrm{~g} / \mathrm{d}$, van den Borne et al., 2006b) or lower concentrations of ME intakes $\left(500 \mathrm{~kJ} / \mathrm{kg}\right.$ of $\mathrm{BW}^{0.85}$ per day, Blome et al., 2003; 600 to $625 \mathrm{~kJ} / \mathrm{kg}$ of $\mathrm{BW}^{0.85}$ per day, Bartlett et al., 2006) when considering calves of similar BW than those in our study. These conditions may contribute to decrease the efficiency of utilization of DN. When considering calves receiving DN amounts below their theoretical requirements (NRC, 2001), efficiency of utilization of DN for growth above maintenance equaled $81 \%$ (Table 9 ). This value is close to the biological value of milk protein $(80 \%$; NRC, 2001) and therefore represents the maximum gross efficiency of utilization of DN above maintenance. This latter value was close to $80 \%$ dur- 
Table 8. Effect of dietary CP on energy balance, respiratory quotient, and nutrient deposition in veal calves during stages 2 and 3 (n $=32$ )

\begin{tabular}{|c|c|c|c|c|c|c|c|c|c|c|c|c|c|}
\hline \multirow[b]{2}{*}{ Item } & \multicolumn{4}{|c|}{ Stage 2} & \multicolumn{4}{|c|}{ Stage 3} & \multirow[b]{2}{*}{ SEM } & \multicolumn{4}{|c|}{$P$-value } \\
\hline & $\mathrm{F} 76^{1}$ & $\mathrm{~F} 88^{1}$ & $\mathrm{~F} 100^{1}$ & $\mathrm{~F} 112^{1}$ & F76 & F88 & F100 & F112 & & Stage & Diet & Week & Diet $\times$ stage \\
\hline \multicolumn{14}{|c|}{ Energy balance, $\mathrm{kJ} / \mathrm{kg}$ of $\mathrm{BW}^{0.85}$ per day } \\
\hline \multicolumn{7}{|l|}{ Heat production ${ }^{2}$} & 519 & 532 & 9 & $<0.01$ & 0.12 & 0.25 & 0.51 \\
\hline As FHP & 299 & 303 & 297 & 321 & 275 & 272 & 267 & 275 & 4 & $<0.01$ & 0.46 & 0.66 & 0.74 \\
\hline As AHP & 54 & 48 & 53 & 54 & 45 & 53 & 55 & 49 & 2 & 0.67 & 0.84 & 0.45 & 0.59 \\
\hline As TEF & 49 & 48 & 51 & 34 & 36 & 42 & 46 & 47 & 2 & 0.51 & 0.57 & 0.29 & 0.17 \\
\hline Total & 401 & 397 & 398 & 406 & 354 & 365 & 365 & 368 & 5 & $<0.01$ & 0.79 & 0.14 & 0.85 \\
\hline \multicolumn{14}{|l|}{ Retained energy } \\
\hline As protein & 77 & 78 & 89 & 91 & 63 & 64 & 68 & 66 & 2 & $<0.01$ & 0.14 & 0.33 & 0.59 \\
\hline As fat & $153^{\mathrm{a}}$ & $113^{\mathrm{bc}}$ & $124^{\mathrm{b}}$ & $119^{\mathrm{bc}}$ & $122^{\mathrm{bc}}$ & $97^{\mathrm{cd}}$ & $86^{\mathrm{d}}$ & $98^{\mathrm{cd}}$ & 4 & $<0.01$ & $<0.01$ & 0.43 & 0.57 \\
\hline Total & $230^{\mathrm{a}}$ & $191^{\mathrm{bcd}}$ & $213^{\mathrm{ab}}$ & $211^{\mathrm{abc}}$ & $184^{\text {cde }}$ & $162^{\mathrm{ef}}$ & $154^{\mathrm{f}}$ & $164^{\mathrm{def}}$ & 5 & $<0.01$ & 0.03 & 0.78 & 0.49 \\
\hline Adjusted $^{3}$ & 240 & 213 & 232 & 229 & 244 & 236 & 235 & 232 & 5 & 0.10 & 0.09 & 0.14 & 0.34 \\
\hline Respiratory quotient & 0.93 & 0.93 & 0.93 & 0.92 & 0.93 & 0.92 & 0.92 & 0.92 & 0.002 & 0.82 & 0.42 & 0.81 & 0.86 \\
\hline \multicolumn{14}{|c|}{ Nutrient deposition, $\mathrm{g} / \mathrm{d}$} \\
\hline Protein & 205 & & 247 & 253 & 247 & 257 & 275 & 268 & 6 & $<0.01$ & 0.06 & 0.97 & 0.76 \\
\hline Lipid & $243^{\mathrm{ab}}$ & $186^{\mathrm{b}}$ & $208^{\mathrm{b}}$ & $199^{\mathrm{b}}$ & $286^{\mathrm{a}}$ & $233^{\mathrm{ab}}$ & $212^{\mathrm{b}}$ & $235^{\mathrm{ab}}$ & 9 & 0.03 & 0.03 & 0.11 & 0.68 \\
\hline \multicolumn{14}{|c|}{ BW gain composition, / kg of gain } \\
\hline Protein, g & & & & & & & 180 & & 3 & 0.15 & 0.65 & 0.99 & 0.58 \\
\hline Lipid, g & $208^{\mathrm{a}}$ & $149^{\mathrm{cd}}$ & $135^{\mathrm{d}}$ & $138^{\mathrm{cd}}$ & $199^{\mathrm{ab}}$ & $177^{\mathrm{abc}}$ & $137^{\mathrm{d}}$ & $163^{\text {bcd }}$ & 7 & 0.23 & $<0.01$ & 0.06 & 0.45 \\
\hline Energy, MJ & $12.4^{\mathrm{a}}$ & $10.0^{\mathrm{bc}}$ & $9.2^{\mathrm{c}}$ & $9.6^{\mathrm{c}}$ & $11.9^{\mathrm{a}}$ & $11.6^{\mathrm{ab}}$ & $9.7^{\mathrm{c}}$ & $10.9^{\mathrm{abc}}$ & 0.3 & 0.09 & $<0.01$ & 0.14 & 0.30 \\
\hline
\end{tabular}

${ }^{\mathrm{a}-\mathrm{f}}$ Least squares means within a row with different superscripts differ $(P<0.05)$.

${ }^{1}$ Crude protein concentrations in diets: F76 = $151 \mathrm{~g} / \mathrm{kg}$ of DM; F88 = $174 \mathrm{~g} / \mathrm{kg}$ of DM; F100 = $196 \mathrm{~g} / \mathrm{kg}$ of DM; F112=221 g/kg of DM.

${ }^{2} \mathrm{FHP}=$ fasting heat production; $\mathrm{AHP}=$ activity heat production; $\mathrm{TEF}=$ thermic effect of feeding.

${ }^{3}$ Retained energy was adjusted for the same ME intake (672 and $611 \mathrm{~kJ} / \mathrm{kg}$ of BW $\mathrm{BW}^{0.85}$ per day for stages 2 and 3 , respectively) and AHP (57 and $52 \mathrm{~kJ} / \mathrm{kg}$ of $\mathrm{BW}{ }^{0.85}$ per day for stages 2 and 3 , respectively). 


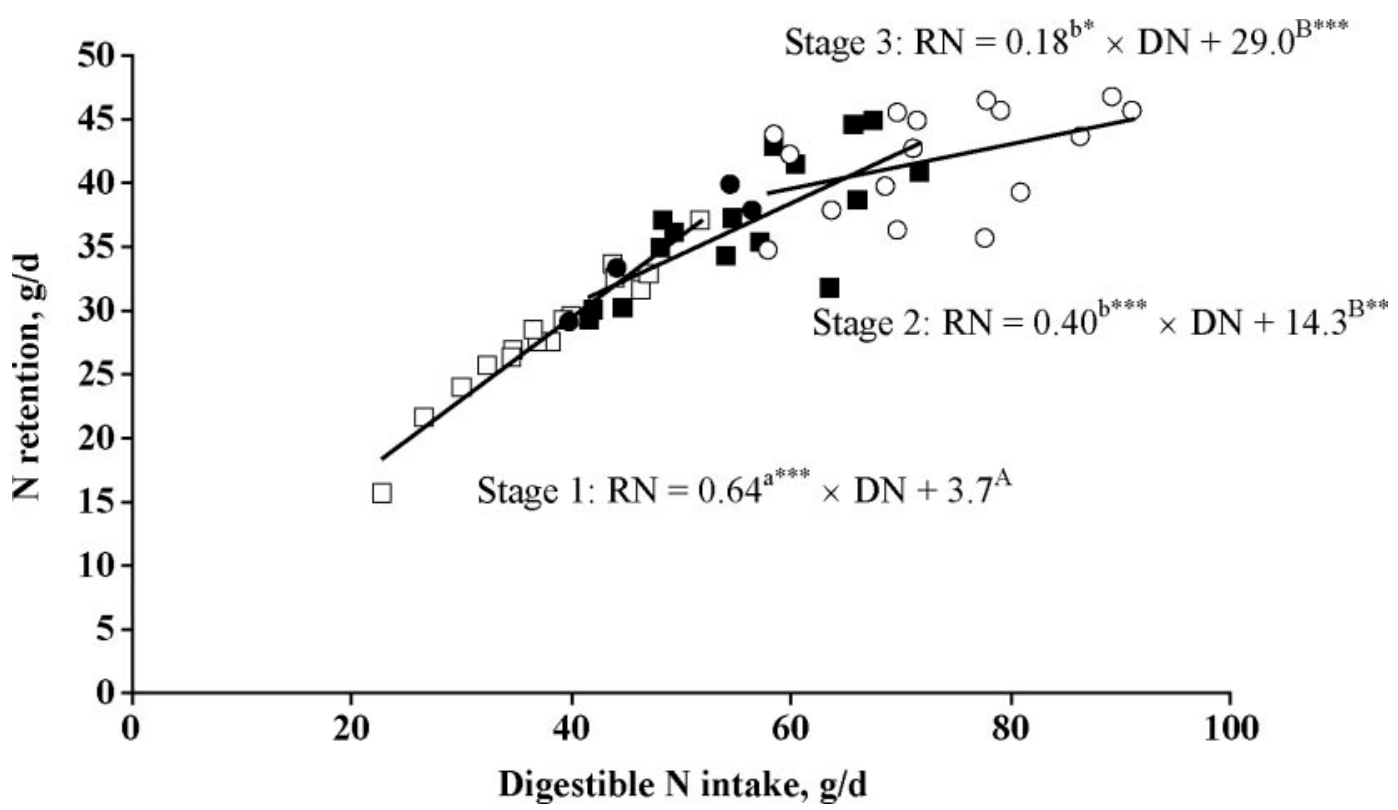

Figure 1. Relationship between $\mathrm{N}$ retention $(\mathrm{RN})$ and digestible $\mathrm{N}$ intake (DN) in veal calves at 3 stages of fattening: $\square$, stage 1 ; $\mathbf{\square}$, stage

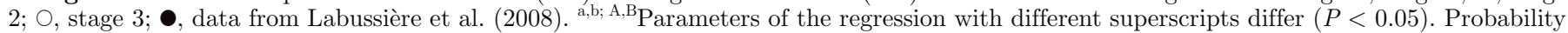
of equality of coefficient to $0:{ }^{*} P<0.05,{ }^{* *} P<0.01, * * * P<0.001$.

ing stage 1 whatever the dietary $\mathrm{CP}$ content but was decreased below $75 \%$ with diets F100 and F112 during stage 2 and with diets F88, F100, and F112 during stage 3, indicating that $\mathrm{DN}$ allowance with these diets was greater than requirements of the calves.

The marginal efficiency of DN retention has been estimated as the slope of the linear regression between DN and RN. The relationship during stage 1 was linear, and the marginal efficiency of DN retention equaled $64 \%$ (Figure 1). This value is greater than that reported by Donnelly and Hutton (1976a; 45\%) but similar to the value reported by Blome et al. (2003; $66 \%$ ). Moreover, the gross efficiency of DN utilization did not significantly decrease with increasing dietary $\mathrm{CP}$ content during stage 1 as reported by Bartlett et al. (2006). The maximal DN allowance (1.77 g/MJ of ME) was therefore insufficient to satisfy maximum potential of the animal for $\mathrm{RN}$ and theoretical $\mathrm{N}$ requirements (increasing from 40 to $48 \mathrm{~g}$ of $\mathrm{DN} / \mathrm{d}$ between diets $\mathrm{G} 76$ and G112, NRC, 2001). The dietary CP content was then further increased in another experiment carried out during stage 1 using $120 \%$ of the reference $\mathrm{CP}$ concentration or $24.6 \%$ CP (Labussière et al., 2008, Figure 1) in calves of similar BW and ME intakes. The measured gross efficiency of RN remained high $(72 \%)$, and DN allowance could therefore be increased up to 1.88 $\mathrm{g} / \mathrm{MJ}$ of ME, which is lower than the value calculated from data of Bartlett et al. (2006; $2 \mathrm{~g} / \mathrm{MJ}$ of ME). During stage 2, the linear relationship between DN and $\mathrm{RN}$ results to a marginal efficiency of $\mathrm{DN}$ retention equaling 40\%, which is consistent with that estimated by Gerrits et al. (1996) in heavy calves. When testing a linear-plateau relationship to fit data from stage 2, slope in the ascending phase was therefore increased up to $56 \%$, but residual standard error was twice the value in case of a linear relationship. There was no statistical

Table 9. Prediction equations for determining $\mathrm{N}$ requirements in veal calves

\begin{tabular}{|c|c|c|c|}
\hline Item & $\mathrm{n}$ & Residual SD & $\mathrm{R}^{2}$ \\
\hline $\begin{array}{l}\mathrm{DN}^{1}(\mathrm{~g} / \mathrm{kg} \text { of } \mathrm{DMI})=-2.5^{* *}(\mathrm{SE}=0.7)+1.00^{* * *}(\mathrm{SE}=0.02) \times \mathrm{NI}(\mathrm{g} / \mathrm{kg} \text { of DMI }) \\
\mathrm{RN}\left(\mathrm{g} / \mathrm{kg} \text { of } \mathrm{BW}^{0.85} \text { per day }\right)=-0.07(\mathrm{SE}=0.06)+0.81^{* * *}(\mathrm{SE}=0.07) \times \mathrm{DN}\left(\mathrm{g} / \mathrm{kg} \text { of BW } \mathrm{BW}^{0.85} \text { per day }\right) \\
\mathrm{RN}(\mathrm{g} / \mathrm{d})=28.3(\mathrm{SE}=0.4) \times \mathrm{BW} \text { gain }(\mathrm{kg} / \mathrm{d})\end{array}$ & $\begin{array}{l}48 \\
26^{2} \\
48\end{array}$ & $\begin{array}{l}0.7 \\
0.03 \\
4.0\end{array}$ & $\begin{array}{l}0.98 \\
0.86 \\
0.99^{3}\end{array}$ \\
\hline
\end{tabular}

${ }^{1} \mathrm{DN}=$ digestible $\mathrm{N} ; \mathrm{NI}=\mathrm{N}$ intake; $\mathrm{RN}=$ retained $\mathrm{N}$.

${ }^{2}$ Only the data from calves receiving $\mathrm{N}$ amounts below their theoretical $\mathrm{N}$ requirements (calculated according to NRC, 2001) were considered in the model for estimating metabolic urinary N. The effect of stage of fattening was not significant.

${ }^{3}$ Because no intercept was specified in the model, $\mathrm{R}^{2}$ was redefined as 1 - sum of squares of error (model without intercept)/total sum of squares (model with intercept).

** $P<0.01 ; * * * P<0.001$. 
difference in $\mathrm{RN}$ between diets during stages 2 and 3 . It can nevertheless be noted that RN during stage 2 was numerically greater with diet F100 than with diets F76 or F88, whereas there was a negligible increase in RN between diets F100 and F112. This may indicate that $\mathrm{N}$ requirements are probably satisfied with diet F100 during stage 2, which provided $1.51 \mathrm{~g}$ of DN/MJ of ME. During stage 3, there was no difference in RN between dietary $\mathrm{CP}$ concentration. Consequently, marginal efficiency of DN retention was low and equaled $18 \%$, which is largely lower than the values reported by Gerrits et al. (1996; less than 30\%). This has to be related to the decrease in gross efficiency of utilizing DN (from 66.0 to $49.5 \%$ during stage 3 ) according to results reported by Gerrits et al. (1996). During this stage, a DN allowance of $1.20 \mathrm{~g} / \mathrm{MJ}$ of ME (corresponding to a F76 diet) may probably satisfy $\mathrm{N}$ requirements of the calves. Nevertheless, the latter value has to be considered cautiously, because variation of $\mathrm{RN}$ response to DN allowance increased as animals got older (Figure 1), which may decrease the precision of requirement estimation.

Several explanations have been put forward to explain the decrease in marginal efficiency of DN retention (van den Borne et al., 2006a). First, DN intake may have exceeded $\mathrm{N}$ requirements (70 g of $\mathrm{DN} / \mathrm{d}, \mathrm{NRC}, 2001$ ) for all dietary $\mathrm{CP}$ concentrations (except F76 during stage 3 ), thereby affecting marginal N retention. Second, a lactose-induced insulin resistance may develop as the calf gets older (Hostettler-Allen et al., 1994), which can depress the ability of cells to uptake the extra nutrient supply out of the blood and therefore induce a low efficiency of protein utilization as animals get older. This assumption is also confirmed by the urinary glucose excretion that increased in the present trial from $8 \mathrm{~g} / \mathrm{d}$ at stage 1 to 78 and $125 \mathrm{~g} / \mathrm{d}$ at stages 2 and 3 (average over dietary $\mathrm{CP}$ contents; results not presented).

The maximum $\mathrm{N}$ gain increased with age from 32.8 to 40.5 and $44.0 \mathrm{~g} / \mathrm{d}$ during stage 1,2 , and 3 , respectively. Our data suggests that this maximum is below the potential $\mathrm{N}$ gain at stage 1 , because daily $\mathrm{RN}$ could be further increased up to $35.0 \mathrm{~g} / \mathrm{d}$ (average value for 4 calves receiving a $246 \mathrm{~g}$ of $\mathrm{CP} / \mathrm{kg}$ of $\mathrm{DM}$ diet, Labussière et al., 2008, Figure 1). Diaz et al. (2001) observed $\mathrm{N}$ gains between 50 and $60 \mathrm{~g} / \mathrm{d}$ with 65-to 105-kg male Holstein calves that received a $30 \%$ greater energy supply (900 vs. $672 \mathrm{~kJ}$ of $\mathrm{ME} / \mathrm{kg}$ of $\mathrm{BW}^{0.85}$ per day). In conclusion, it appears that the $\mathrm{N}$ requirement for growth is very high in young veal calves (stage 1), allowing for a further increase in CP content of milk replacers; further investigation would be performed to assess if DN allowance should be further increased up to $1.88 \mathrm{~g}$ of $\mathrm{DN} / \mathrm{MJ}$ of $\mathrm{ME}$.

\section{Utilization of Dietary Energy}

The metabolizability of DE decreased numerically from $97 \%$ at stage 1 to $94 \%$ at stage 2 and $93 \%$ at stage 3 due to increasing energy losses in the urine (Tables 3 and 6). Data concerning stage 1 are in agreement with those of Diaz et al. (2001) but are greater than those of Blome et al. (2003). Nevertheless, the values for stages 2 and 3 are slightly lower than those measured by Gerrits et al. (1996) with calves of similar BW (120 kg, ME:DE $=96.5 \% ; 200 \mathrm{~kg}, \mathrm{ME}: \mathrm{DE}=95.3 \%$ ). On average for all treatments, our calves were nevertheless fed greater amounts of DN, and they may have excreted greater urinary $\mathrm{N}$, thus decreasing the ratio ME:DE.

During stage 1 , the fraction of energy retained as protein increased linearly from 36 to $55 \%$ as dietary CP increased, which is in agreement with results of Blome et al. (2003) and Bartlett et al. (2006). During stages 2 and 3 , the composition of retained energy differed between diet F76 and the other diets (67 vs. $55 \%$ as fat). The partitioning of energy between protein and lipid differed also between stages. Up to $55 \%$ of total energy was retained as protein during stage 1 , whereas this was less than $45 \%$ for stages 2 and 3. Similar results were obtained by Vermorel et al. (1974). These results are consistent with the numerical reduction in respiratory quotient with age, indicating that increasing quantities of absorbed $\mathrm{N}$ are catabolized as animals get older (Gerrits et al., 1996).

Similar to results reported by Donnelly and Hutton (1976a), we did not observe an effect of dietary CP content on total HP, its components, or energy retention (Tables 5 and 8). Nevertheless, dietary CP affected differently the partitioning of energy retention between protein and lipid according to the stages. Previous work in growing pigs indicated that the gross efficiency of using ME differed for different nutrients (van Milgen et al., 2001) and body tissue deposition (protein vs. fat, Noblet et al., 1999). In our experiment, the substitution of fat and lactose for protein was not associated with variations in HP. Moreover, variations in dietary $\mathrm{CP}$ contents caused variations in the lipid deposition and in the fat content of $\mathrm{BW}$ gain. These variations were not associated with variations in HP: daily digestible fat intake was more than twice greater than the fat deposition in calves. Consequently, calves would deposit dietary fatty acids directly as body fat, which is associated with a low energy cost of deposition (van den Borne et al., 2007).

\section{Growth Performance and Composition of BW Gain}

During stage 1 , the increased dietary CP content resulted in a numerical increase in BW gain, which agrees 
with previous studies (Blome et al., 2003; Bartlett et al., 2006). In agreement with Gerrits et al. (1996), the BW gain was affected by dietary $\mathrm{CP}$ concentration during stage 2 , whereas there was no effect during stage 3 . The difference in response between stages may be partly explained by the relatively narrow range in dietary CP. It can also be argued that BW gain is estimated with a low precision $(\mathrm{SEM}=0.03 \mathrm{~kg}$ ) due to the short duration of measurement and the small number of animals per treatment.

In agreement with results of others (Diaz et al., 2001; Bartlett et al., 2006), the protein content of BW gain increased from 154 to $188 \mathrm{~g} / \mathrm{kg}$ gain during stage 1 between diet G76 and the 3 other diets. The former could be explained by the low $\mathrm{N}$ supply, which could have limited protein deposition, or by the greater fat deposition, which may have diluted protein content in BW gain. The latter was greater than the value obtained from the relationship between $\mathrm{RN}$ and $\mathrm{BW}$ gain (177 $\mathrm{g} / \mathrm{kg}$ of $\mathrm{BW}$ gain). It was also greater than the values obtained with male Holstein calves receiving diets with similar or greater CP contents (Tikofsky et al., 2001), but the latter were obtained using the comparative slaughter technique, and the balance technique used in the present experiment may have overestimated $\mathrm{RN}$ (Toullec et al., 1978). During stages 2 and 3, the protein content of BW gain averaged 170 and $183 \mathrm{~g} / \mathrm{kg}$ of BW gain, respectively. These values are lower than those measured in veal calves weighing 145 to $187 \mathrm{~kg}$ and receiving similar amounts of ME and N (214 g/ $\mathrm{kg}$ of BW gain; Vermorel et al., 1974) but greater than those calculated from the results of Gerrits et al. (1996; 155 to $175 \mathrm{~g} / \mathrm{kg}$ of BW gain).

During stage 1, the lipid content of BW gain decreased with increasing dietary $\mathrm{CP}$ content, and it notably decreased for diet G112. The latter (90 g/ $\mathrm{kg}$ of BW gain) is markedly lower than values measured in male calves of similar BW and for a similar dietary CP concentration $(184 \mathrm{~g} / \mathrm{kg}$ of BW gain; Donnelly and Hutton, 1976b; $129 \mathrm{~g} / \mathrm{kg}$ of BW gain;, Bartlett et al., 2006), but it is consistent with values measured by Blome et al. (2003; $87 \mathrm{~g} / \mathrm{kg}$ of BW gain) with male Holstein calves. As suggested earlier by Diaz et al. (2001), the quantity of energy offered with diet G112 (and perhaps also with diet G120; Labussière et al., 2008) may not have been sufficient to ensure maximum fat deposition and BW gain. During stage 2, there was no effect of dietary CP content on the lipid content of BW gain between diets F88 and F112: only diet F76 resulted in a greater value for lipid concentration. During stage 3, lipid content of BW gain was lower with diet F100, and this may be partly due to the lower ME intake. These values are lower than those measured by Vermorel et al. (1974) with male calves of the Normande breed, but they are in the range of values reported by Meulenbroeks et al. (1986) with Dutch Friesian and Holstein Friesian crossbred male calves (125 to $203 \mathrm{~g} / \mathrm{kg}$ of BW gain).

\section{CONCLUSIONS}

The protein and fat deposition in veal calves was affected by the dietary $\mathrm{CP}$ concentration and mainly when calves were young. The effect of dietary $\mathrm{CP}$ on protein deposition was less pronounced or even negligible as calves got older, resulting in a low marginal efficiency of $\mathrm{N}$ utilization. The endogenous fecal $\mathrm{N}$ excretion was estimated as $2.5 \mathrm{~g} / \mathrm{kg}$ of DMI per day, whereas metabolic urinary (maintenance) $\mathrm{N}$ was 0.07 $\mathrm{g} / \mathrm{kg}$ of $\mathrm{BW}^{0.85}$ per day. The $\mathrm{N}$ content of $\mathrm{BW}$ gain averaged $28 \mathrm{~g} / \mathrm{kg}$. These values can be used in the calculation of the $\mathrm{N}$ requirement of veal calves over their entire fattening period.

\section{ACKNOWLEDGMENTS}

This experiment was part of a research project conducted jointly by INRA and Institut de l'Elevage and was financed by the French regions of Bretagne and Pays de la Loire and the French veal calf production organizations Interveaux and SDVF (Paris, France). We thank A. Chauvin, B. Janson, F. Le Gouevec, V. Piedvache, J.-F. Rouaud (INRA), and O. Glais and R. Leborgne (Institut de l'Elevage) for animal care; B. Fontaine and D. Guillard (INRA) for transport of the animals; and Y. Jaguelin and A. Pasquier (INRA) for laboratory analyses. We also thank M. Vermorel and P. Patureau-Mirand for reviewing the manuscript.

\section{REFERENCES}

AOAC. 1990. Official Methods of Analysis. 15th ed. AOAC International, Arlington, VA.

Bartlett, K. S., F. K. McKeith, M. J. Vandehaar, G. E. Dahl, and J. K. Drackley. 2006. Growth and body composition of dairy calves fed milk replacers containing different amounts of protein at two feeding rates. J. Anim. Sci. 84:1454-1467.

Blome, R. M., J. K. Drackley, F. K. McKeith, M. F. Hutjens, and G. C. McCoy. 2003. Growth, nutrient utilization, and body composition of dairy calves fed milk replacers containing different amounts of protein. J. Anim. Sci. 81:1641-1655.

Brouwer, E. 1965. Report of sub-committee on constants and factors. Pages 441-443 in Energy metabolism. Proceedings of the 3rd Symposium of the European Association of Animal Production, Troon, UK. Acad. Press, London, UK.

Davis, C. L., and J. K. Drackley. 1998. The Development, Nutrition, and Management of the Young Calf. Iowa State University Press, Ames.

Diaz, M. C., M. E. Van Amburgh, J. M. Smith, J. M. Kelsey, and E. L. Hutten. 2001. Composition of growth of Holstein calves fed milk replacer from birth to 105-kilogram body weight. J. Dairy Sci. 84:830-842.

Donnelly, P. E., and J. B. Hutton. 1976a. Effects of dietary protein and energy on the growth of Friesian bull calves 1. Food intake, growth, and protein requirements. N. Z. J. Agric. Res. 19:289-297. 
Donnelly, P. E., and J. B. Hutton. 1976b. Effects of dietary protein and energy on the growth of Friesian bull calves 2. Effects of level of feed intake and dietary protein content on body composition. N. Z. J. Agric. Res. 19:409-414.

Gerrits, W. J., G. H. Tolman, J. W. Schrama, S. Tamminga, M. W. Bosch, and M. W. Verstegen. 1996. Effect of protein and protein-free energy intake on protein and fat deposition rates in preruminant calves of 80 to $240 \mathrm{~kg}$ live weight. J. Anim. Sci 74:2129-2139.

Guilloteau, P., R. Toullec, J. F. Grongnet, P. Patureau-Mirand, J. Prugnaud, and D. Sauvant. 1986. Digestion of milk, fish and soyabean protein in the preruminant calf: Flow of digesta, apparent digestibility at the end of the ileum and amino acid composition of ileal digesta. Br. J. Nutr. 55:571-592.

Hostettler-Allen, R. L., L. Tappy, and J. W. Blum. 1994. Insulin resistance, hyperglycemia, and glucosuria in intensively milk-fed calves. J. Anim. Sci. 72:160-173.

Labussière, E., G. Bertrand, and J. Noblet. 2007. Les besoins protéiques et énergétiques des veaux de boucherie: Détermination et facteurs de variation. INRA Prod. Anim. 20:355-368.

Labussière, E., S. Dubois, J. van Milgen, G. Bertrand, and J. Noblet. 2008. Fasting heat production and energy cost of standing activity in veal calves. Br. J. Nutr. doi:10.1017/S0007114508980648

Lodge, G. A., and E. E. Lister. 1973. Effects of increasing the energy value of whole milk diet for calves. 1 . Nutrient digestibility and nitrogen retention. Can. J. Anim. Sci. 53:307-316.

Meulenbroeks, J., M. W. A. Verstegen, W. Van Der Hel, S. Korver, and G. Kleinhout. 1986. The effect of genotype and metabolizable energy intake on protein and fat gain in veal calves. Anim. Prod. 43:195-200.

Noblet, J., Y. Henry, and S. Dubois. 1987. Effect of protein and lysine levels in the diet on body gain composition and energy utilization in growing pigs. J. Anim. Sci. 65:717-726.

Noblet, J., C. Karege, S. Dubois, and J. van Milgen. 1999. Metabolic utilization of energy and maintenance requirements in growing pigs: Effects of sex and genotype. J. Anim. Sci. 77:1208-1216.

NRC. 2001. Nutrient Requirements of the Young Calf. Pages 214233 in Nutrient Requirements of Dairy Cattle. Natl. Acad. Press, Washington, DC.

Roy, J. H. B., I. J. F. Stobo, and H. J. Gaston. 1970. The nutrition of the veal calf. 3. A comparison of liquid skim milk with a diet of reconstituted spray-dried skim-milk powder containing $20 \%$ margarine fat. Br. J. Nutr. 24:459-475.

SAS. 2004. SAS/STAT ${ }^{\circledR} 9.1$ User's Guide. SAS Institute Inc., Cary, $\mathrm{NC}$

Ternouth, J. H., I. J. F. Stobo, and J. H. B. Roy. 1985. The effect of milk substitute concentration upon the intake, digestion and growth of calves. Anim. Prod. 41:151-159.
Tikofsky, J. N., M. E. Van Amburgh, and D. A. Ross. 2001. Effect of varying carbohydrate and fat content of milk replacer on body composition of Holstein bull calves. J. Anim. Sci. 79:2260-2267.

Tolman, G. H., and G. M. Beelen. 1995. Flux d'azote et d'acides aminés endogènes à la fin de l'iléon du veau de boucherie et digestibilité vraie iléale des protéines du lait écrémé, d'un concentrat soluble de blé et d'un isolat de soja. Pages 199-216 in Le veau à l'horizon de l'an 2000, Le Mans, France. Fédération de la Vitellerie Française, Paris, France.

Toullec, R., P. Thivend, M. Vermorel, L. Guéguen, J.-L. Troccon, R. Guilhermet, and Y. Geay. 1978. Pages 245-296 in Alimentation des ruminants: Principes de la nutrition et de l'alimentation des ruminants, besoins alimentaires des animaux, valeur nutritive des aliments. R. Jarrige, ed. INRA, Versailles, France.

van den Borne, J. J. G. C., G. E. Lobley, M. W. A. Verstegen, J. M. Muijlaert, S. J. J. Alferink, and W. J. J. Gerrits. 2007. Body fat deposition does not originate from carbohydrates in milk-fed calves. J. Nutr. 137:2234-2241.

van den Borne, J. J. G. C., J. M. A. J. Verdonk, J. W. Schrama, and W. J. J. Gerrits. 2006a. Reviewing the low efficiency of protein utilization in heavy preruminant calves - A reductionist approach. Reprod. Nutr. Dev. 46:121-137.

van den Borne, J. J. G. C., M. W. A. Verstegen, S. J. J. Alferink, R. M. M. Giebels, and W. J. J. Gerrits. 2006b. Effects of feeding frequency and feeding level on nutrient utilization in heavy preruminant calves. J. Dairy Sci. 89:3578-3586.

van Milgen, J., J. Noblet, and S. Dubois. 2001. Energetic efficiency of starch, protein and lipid utilization in growing pigs. J. Nutr. 131:1309-1318

van Milgen, J., J. Noblet, S. Dubois, and J. F. Bernier. 1997. Dynamic aspects of oxygen consumption and carbon dioxide production in swine. Br. J. Nutr. 78:397-410.

van Weerden, E. J. 1972. Pages 31-44 in Nitrogen balance in relation to protein and amino acid requirements in the veal calf. National Renderers Association, Brussels, Belgium.

Vermorel, M., J. C. Bouvier, Y. Bonnet, and G. Fauconneau. 1973 Construction et fonctionnement de deux chambres respiratoires du type "circuit ouvert" pour jeunes bovins. Ann. Biol. Anim. Biochim. Biophys. 13:659-681.

Vermorel, M., J. C. Bouvier, P. Thivend, and R. Toullec. 1974. Utilisation énergétique des aliments d'allaitement par le veau préruminant à l'engrais à différents poids. Pages 143-146 in Energy Metabolism of Farm Animals. Proceedings of the 6th Symposium, Stuttgart, Germany. University of Hohenheim, Stuttgart, Germany. 